\title{
Kompetencje terapeutyczne nauczyciela w zmieniającej się przestrzeni edukacyjnej
}

W świetle nowych tendencji w systemie edukacji, gdy pojawiły się nowe aspiracje społeczne, zmienił się poziom oczekiwań i wymagań względem szkoły, inaczej także pojmuje się rolę nauczyciela. Zmiany w systemie edukacji wymuszają również zmiany wymagań stawianych nauczycielom. Nauczyciela winno się postrzegać jako kreatora i promotora zmian nie tylko w przedmiocie projektowania dydaktycznego, ale także w formułowaniu pewnej perspektywy edukacyjnej. Nie wystarcza już, by nauczyciel wyłącznie kształcił i wychowywał. Funkcje nauczyciela wciąż się rozrastają. Oczekiwania społeczne w stosunku do nauczycieli dotyczą przede wszystkim sfery ich kompetencji oraz skuteczności realizacji zadań edukacyjnych, wywiązywania się z narzucanych obowiązków zawodowych i umiejętności wypełniania „misji” zawodowej-roli w przestrzeni społecznej i w środowisku lokalnym.

\section{Terminologiczne ujęcie kompetencji w kontekście pedagogicznym}

Termin kompetencje, ze względu na szeroki zakres tematyczny, wieloaspektowość i niejednoznaczność, znajduje w literaturze 
przedmiotu wiele różnorodnych definicji ${ }^{1}$. Kompetencja to zdolność wykorzystywania przez człowieka własnej wiedzy, umiejętności oraz cech osobowości do osiągania zadań i celów związanych z zajmowanym stanowiskiem pracy. W ujęciu słownikowym słowo kompetencja (łac. competentia = odpowiedniość, zgodność, uprawnienia do działania) oznacza zakres pełnomocnictw i uprawnień, zakres czyjejś wiedzy, umiejętności, odpowiedzialności ${ }^{2}$. Słownik języka polskiego definiuje kompetencje jako: „formalny zakres uprawnień do jakiegoś działania, zwykle sprawowania władzy pełnomocnictwa” oraz „odpowiedni zakres wiedzy i umiejętności, fachowość, umiejętność znania się na rzeczy"3. Ireneusz Woźniak trafnie zauważa, że w języku polskim termin kompetencje oznaczał do tej pory „posiadanie uprawnień do podejmowania decyzji lub zajmowania się daną sprawą", tymczasem w języku angielskim słowo competence oznacza posiadanie umiejętności, talentu i zdolności do wykonywania określonej pracy czy też zajmowania eksponowanej pozycji zawodowej ${ }^{4}$. Zdaniem Marii Czerepaniak-Walczak kompetencja to „szczególna właściwość, wyrażająca się w demonstrowaniu na wyznaczonym przez społeczne standardy poziomie, umiejętności adekwatnego zachowania się, w świadomości potrzeby i konsekwencji takiego właśnie zachowania oraz w przyjmowaniu na siebie odpowiedzialności za nie"5. Osoba kompetentna efektywnie radzi sobie w danym zakresie, wykorzystując wiedzę teoretyczną, własne umiejętności i sprawności, odczuwa potrzebę danego zachowania i jest świadoma jego konsekwencji.

$\mathrm{W}$ pedagogice pojęcie kompetencje używane jest $\mathrm{w}$ odniesieniu do umiejętności umożliwiających realizację określonych zadań

1 B. Muchacka, M. Szymański, Kompetencje jako transgresyjny potencjał nauczycieli, [w:] B. Muchacka, M. Szymański (red.), Nauczyciel w świecie współczesnym, Oficyna Wydawnicza „Impuls”, Kraków 2008, s. 42.

2 J. Tokarski (red.), Słownik wyrazów obcych, PWN, Warszawa 1980, s. 372.

3 B. Dunaj (red.), Słownik współczesnego języka polskiego, PWN, Warszawa, 1996, s. 398.

4 I. Woźniak, Standard kwalifikacji zawodowych jako łącznik między wymaganiami rynku pracy a edukacją zawodową, [w:] S.M. Kwiatkowski, I. Woźniak (red.), Standardy kwalifikacji zawodowych i standardy edukacyjne. Relacje-modele-aplikacje, IBN, Warszawa 2002, s. 28.

$5 \quad$ M. Czerepaniak-Walczak, Aspekty i źródła profesjonalnych refleksji nauczyciela, Wydawnictwo Edytor, Toruń 1997, s. 89, także: Refleksja krytyczna i jej miejsce w dyskusji nad reformowaniem oświaty, „Rocznik Pedagogiczny”, t. 20. 
dydaktyczno-wychowawczych oraz optymalne funkcjonowanie w obszarze procesów edukacyjnych a także możliwości i zdolności nauczyciela w zakresie osobistej samorealizacji ${ }^{6}$. Kategoria kompetencje w odniesieniu do nauczyciela definiowana jest często jako spektrum jego zdolności, integracja wiedzy i umiejętności, suma kwalifikacji zdobywanych $\mathrm{w}$ toku kształcenia wraz $\mathrm{z}$ pozyskiwanym doświadczeniem zawodowym oraz zakresem zdobywanych uprawnień do wykonywanego zawodu. W związku z powyższym kompetencje nauczyciela niejednokrotnie błędnie utożsamiane są z posiadanymi przez niego kwalifikacjami formalnymi, które stanowią jedynie zadatek kompetencji?.

Według Jana Průchy przez pojęcie kompetencje nauczyciela należy rozumieć jako „zbiór profesjonalnych umiejętności, wiedzy, wartości oraz postaw, którymi musi dysponować każdy nauczyciel, aby mógł efektywnie wykonywać swoją pracę"8. Definicja ta kładzie szczególny nacisk na profesjonalizm oraz dojrzałość intelektualną, moralną, społeczną nauczyciela - właściwości jego osoby wyznaczane przez standardy jego pracy zawodowej. Zatem kompetencje nauczycielskie to struktura poznawcza złożona z umiejętności, wiedzy, dyspozycji i postaw nauczycieli niezbędnych dla skutecznej realizacji zadań wynikających z określonej koncepcji edukacyjnej.

\section{U źródeł kompetencji terapeutycznych nauczyciela}

Rozporządzenie Ministra Edukacji Narodowej z dnia 9 sierpnia 2017 r. w sprawie zasad udzielania i organizacji pomocy psychologiczno-pedagogicznej w publicznych przedszkolach, szkołach

$6 \quad$ W. Okoń, Nowy słownik pedagogiczny, Warszawa 2004, Wydawnictwo Akademickie Żak, s. 185.

7 B. Muchacka, M. Szymański, Kompetencje jako transgresyjny potencjał nauczycieli..., s. 42.

8 J. Průcha, Pedeutologia, [w:] B. Śliwerski (red), Pedagogika, t. 2: Pedagogika wobec edukacji, polityki oświatowej i badań naukowych, przekł. B. Śliwerski, Wydawnictwo GWP, Gdańsk 2006 s. 306.

9 E. Goźlińska, F. Szlosek, Podręczny słownik nauczyciela kształcenia zawodowego, Wydawnictwo Instytutu Technologii Eksploatacji, Radom 1997, s. 52. 
i placówkach nakłada na nauczycieli obowiązek prowadzenia działań pedagogicznych mających na celu:

1. rozpoznawanie indywidualnych potrzeb rozwojowych i edukacyjnych oraz możliwości psychofizycznych uczniów;

2. określanie mocnych stron, predyspozycji, zainteresowań i uzdolnień uczniów;

3. rozpoznawanie przyczyn niepowodzeń edukacyjnych lub trudności w funkcjonowaniu uczniów, w tym barier i ograniczeń utrudniających funkcjonowanie uczniów i ich uczestnictwo w życiu przedszkola, szkoły lub placówki;

4. podejmowanie działań sprzyjających rozwojowi kompetencji oraz potencjału uczniów w celu podnoszenia efektywności uczenia się i poprawy ich funkcjonowania;

5. współpracę $\mathrm{z}$ poradnią w procesie diagnostycznym i postdiagnostycznym, w szczególności w zakresie oceny funkcjonowania uczniów, barier i ograniczeń w środowisku utrudniającym funkcjonowanie uczniów i ich uczestnictwo w życiu przedszkola, szkoły lub placówki oraz efektów działań podejmowanych $\mathrm{w}$ celu poprawy funkcjonowania ucznia oraz planowania dalszych działań ${ }^{10}$.

Jak słusznie zauważa Mirosława Brasławska-Haque, taki zakres kompetencji przypisywany był głównie pracownikom poradni psychologiczno-pedagogicznych (lub zatrudnionym w szkole) pedagogom, psychologom, doradcom zawodowym, terapeutom. Obecnie taką pomoc mają świadczyć przede wszystkim nauczyciele, którzy w związku z tym zobowiązani zostali do posiadania odpowiednich kwalifikacji, a co za tym idzie kompetencji i umiejętności umożliwiających wywiązywanie się z nałożonych obowiązków ${ }^{11}$.

W literaturze przedmiotu można odnaleźć zarówno pojęcie kompetencji terapeutycznych, jak i umiejętności terapeutycznych. Często są stosowane zamiennie. Niekiedy związane są z kompetencjami diagnostycznymi oraz umiejętnościami i oddziaływaniami z zakresu terapii pedagogicznej ${ }^{12}$, a czasem utożsamiane są także z kwalifikacjami terapeutycznymi.

10 Rozporządzenie Ministra Edukacji Narodowej z dnia 9 sierpnia 2017 r. w sprawie organizacji i udzielania pomocy psychologiczno-pedagogicznej w przedszkolach, szkołach i placówkach (Dz.U. 2017, poz. 1591 z poźn. zm.).

11 M. Brasławska-Haque, Kompetencje terapeutyczne współczesnego nauczyciela, http:// rep.up.krakow.pl/xmlui/bitstream/handle/11716/169/0051_20150303_mg_ra_ kompetencje_terapeutyczne_wspolczesnego_m_braslawska.pdf?sequence=1\&isAllowed =y (dostęp: 10.09.2019)

12 D. Wosik-Kawala, T. Zubrzycka-Maciąg (red.), Kompetencje diagnostyczne i terapeutyczne nauczyciela, Oficyna Wydawnicza „Impuls”, Kraków 2011, s. 7-9. 
Źródeł terapeutycznych kompetencji nauczyciela poszukiwać należy w założeniach psychologii humanistycznej, której tezy znalazły swoje odzwierciedlenie w koncepcji nauczyciela autorstwa C. Rogersa. W myśl tejże koncepcji, nauczyciel powinien odznaczać się: 1) wysokimi kompetencjami (szczególnie umiejętnościami diagnozy możliwości uczniowskich i ich rozwoju), 2) autentycznością i uczciwością w relacjach z uczniami, 3) empatycznym zrozumieniem (głęboką wrażliwością wobec uczniowskich potrzeb, pragnień, indywidualnych celów i marzeń, a także ich problemów, postaw, wartości i naturalnych wątpliwości) oraz 4) zaufaniem wobec umiejętności uczniów, wiarą w ich naturalne pragnienie rozwoju i potrzebę zdobywania kompetencji ${ }^{13}$.

Każdy uczeń dysponuje wewnętrznym potencjałem, umiejętnościami iindywidualnymi możliwościami pozwalającymi mu nazrozumienie siebie samego oraz aktywną kreację własnego profilu intelektualnego i osobowego, modyfikację postaw i kontrolę zachowań. Jednak wykorzystanie przez nauczyciela-wychowawcę owego wewnętrznego potencjału ucznia możliwe jest jedynie wówczas, kiedy stworzy on odpowiedni klimat pedagogiczny - wartościowe relacje interpersonalne ${ }^{14}$. Według C. Rogersa odpowiedni klimat pedagogiczny wspomagający uczenie się sprawia, że uczniowie „stają się godni zaufania, kreatywni, umotywowani, silni i konstruktywni - zdolni do osiągania rzeczy niewyobrażalnych"15. Chodzi tu o tworzenie odpowiedniej atmosfery pracy przepełnionej życzliwością, chęcią niesienia wzajemnej pomocy, okazywania zrozumienia, wzajemnego szacunku i zaufania. Stosunki między nauczycielami a uczniami, a także między uczniami w istotny sposób wpływają na postawę wobec szkoły i nauki. Pozytywny klimat z punktu widzenia uczniów to taki, w którym nie ma sytuacji stresowych; dzieci mają możliwość własnej samorealizacji; odczuwają, że nauczycielom zależy na ich rozwoju; czują, że są akceptowani; zawsze wiedzą czego się od nich oczekuje; przeżywają wspólnie sukcesy i radość ze swych działań; nauczyciel jest wobec wszystkich sprawiedliwy ${ }^{16}$. Z punktu

$\overline{13}$ W. Strykowski, Szkoła współczesna i zachodzące w niej procesy, [w:] W. Strykowski, J. Strykowska, J. Pielachowski (red.), Kompetencje nauczyciela szkoły współczesnej, Wydawnictwo eMPi ${ }^{2}$, Poznań 2003, s. 3.

14 C. Rogers, Sposób bycia, Dom Wydawniczy REBIS, Poznań 2002, s. 129.

15 Ibidem, s. 213.

16 E. Petlak, Klimat szkoły. Klimat klasy, Wydawnictwo Akademickie Żak, Warszawa 2007, s. 67. 
widzenia nauczycieli o pozytywnym klimacie decydują następujące czynniki: spokojny, twórczy klimat szkoły; demokratyczne zarządzanie szkoła; poszukiwanie nowych pedagogiczno-dydaktycznych sposobów traktowania uczniów; wzajemny szacunek i respekt w relacjach międzyludzkich; twórcza współpraca grona pedagogicznego; możliwość samorealizacji; szacunek dyrekcji szkoły do pracowników i uczniów oraz ogólnie motywujące środowisko pracy ${ }^{17}$. Dobry klimat panujący w zespole klasowym, czy szkolnym może wywoływać poczucie sukcesu w postaci przywiązania emocjonalnego do środowiska rówieśników, w zaspokajaniu potrzeby bezpieczeństwa, chęci do współpracy i wzrostu motywacji do nauki. Negatywny, niezdrowy, stresujący klimat tworzy bariery, konflikty, wycofanie dziecka czy też lęki i fobie szkolne.

Aby zbudować właściwy klimat spotkania edukacyjnego, nauczyciel powinien przede wszystkim zachować swoją autentyczność i szczerość w relacjach z uczniami, uczciwość własnych postaw, uzewnętrznianych opinii, przekonań, myśli, sądów. Autentyzm polega na szczerości, zgodności z samym sobą, spójności własnych wypowiedzi i uczuć z własnym zachowaniem. Autentyzm zakłada otwartość i bezpośredniość, zrywa z fasadowością, graniem ról, pozorami, zakłamaniem i fałszem ${ }^{18}$. Carl Rogers taką postawę nauczyciela określa zamiennie, jako autentyczność, spójność oraz „kongruencja” rozumiana, jako zgodność pomiędzy emocjami i myślami nauczyciela a jego postawą i postępowaniem ${ }^{19}$.

Kiedy nauczyciel jest osobą autentyczną, będąc tym, kim rzeczywiście jest, i wchodzi w relacje z uczniami, nie przyjmując przy tym sztucznej pozy, to ma znacznie większe szanse, by działać skutecznie. (...) Znaczy to również, że osoba wspomagająca uczenie się stawia na bezpośrednie, osobiste spotkanie z uczniami, podchodząc indywidualnie do każdego z nich ${ }^{20}$.

Innym warunkiem determinującym walor pedagogicznych relacji nauczyciela z uczniem jest bezwarunkowa akceptacja ucznia, głęboka sympatia wobec jego podmiotowości i zdolność dostrzegania jego

\footnotetext{
17 Ibidem, s. 70.

18 M. Łobocki, Czynniki warunkujące skuteczność pracy wychowawczej, [w:] M. Łobocki (red.), Praca wychowawcza z dziećmi i młodzieża, Wydawnictwo Uniwersytetu Marii Curie-Skłodowskiej, Lublin 2001, s. 17-18.

19 C. Rogers, Sposób bycia, Dom Wydawniczy REBIS, Poznań 2002, s. 30.

20 Ibidem, s. 283.
} 
niekwestionowanej wartości - niezależnie od waloru jego postaw, charakteru reakcji czy też sprzeczności jego wypowiedzi z oczekiwaniami nauczyciela czy środowiska społecznego ${ }^{21}$. Podmiotowe traktowanie uczestników procesu kształcenia na różnych jego poziomach i szczeblach organizacyjnych, zdaniem Kazimierza Denka, oznacza: „poszanowanie ich prawa do tożsamości, niezależności (autonomii) i odrębności (niepowtarzalności), czyli humanistycznego i partnerskiego do nich podejścia oraz dostrzegania w każdym osoby w sensie personalistycznym" ${ }^{22}$. Nauczyciel ma więc obowiązek szanować każdego ucznia, traktować go z godnością, rozwijać w sobie umiejętność rozumienia jego potrzeb i oczekiwań wobec szkoły. Aby podmiotowość dziecka mogła „wyzwolić” się na zajęciach lekcyjnych i pozalekcyjnych, relacje między nim a nauczycielem powinny przybierać postać dwóch równoprawnych podmiotów. Jak twierdzi Jolanta Szempruch: „Realizacja zasady podmiotowości ucznia wymaga, aby miał on zapewnione warunki programowe i organizacyjne do świadomego, aktywnego, pozytywnie motywowanego współuczestnictwa i partnerstwa w procesie edukacji szkolnej"23. Chodzi zatem o stworzenie dziecku w procesie edukacji takich warunków, by pobudziły one jego świadomą aktywność skierowaną na zdobywanie określonej wiedzy i umiejętności. W trakcie tej działalności uczeń powinien czuć się bezpiecznie i swobodnie, odczuwać satysfakcję z podejmowanych działań i ich wyników. Ponadto powinien umieć pracować i współpracować z rówieśnikami i nauczycielami, by w końcowym efekcie osiągnąć edukacyjny sukces. Gdy stosunki między nauczycielem a uczniami nie układają się właściwie, są oparte na emocjach negatywnych, stanach lękowych, sytuacjach wzajemnej niechęci, poniżania, wrogości, nie ma szans na uniknięcie konfliktów, osiąganie kompromisu czy dobrą komunikację. Proces kształcenia zamiast korzyści i satysfakcji jest wtedy jedną wielką porażką obu stron.

Nauczyciel, który docenia i pozytywnie ocenia indywidualność intelektualną ucznia, konstruuje sytuacje edukacyjne, opierając się

21 C. Rogers, O stawaniu się sobą, Dom Wydawniczy REBIS, Poznań 2002, s. 60.

22 K. Denek, Podmiotowość w procesie kształcenia, „Wychowanie na co Dzień” 2003, nr 10-11, s. 4.

23 J. Szempruch, Nauczyciel w zmieniającej się szkole - funkcjonowanie i rozwój zawodowy, Wydawnictwo Oświatowe FOSZE, Rzeszów 2001, s. 159. 
na poczuciu bezpieczeństwa intelektualnego i emocjonalnego. Owa bezwarunkowa akceptacja ucznia i sympatia wobec jego podmiotowości zapewnia uczniowi autonomię intelektualną, a związane $\mathrm{z}$ nią poczucie bezpieczeństwa emocjonalnego pozwala rozwijać mu zdolności, pasje i zainteresowania, swobodnie wypowiadać swoje opinie i poglądy, zdobywać doświadczenie.

Z ideą bezwarunkowej akceptacji ucznia wiąże się kolejny postulat formułowany przez C. Rogersa - umiejętność empatycznego słuchania, a w konsekwencji zdolność do empatycznego zrozumienia ucznia. Troska nauczyciela wobec ucznia implikuje jego naturalne, autentyczne poczucie bezpieczeństwa emocjonalnego, ciepła i akceptacji, jakże potrzebne dla zaistnienia i rozwoju nowych idei, twórczej działalności, nowatorstwa i kreatywności intelektualnej ucznia.

Małgorzata Feiner za najważniejszą powinność nauczycieli uznaje wspieranie, wspomaganie rozwoju uczniów, polegające przede wszystkim na stwarzaniu jak najkorzystniejszych warunków do ich samorealizacji i samodoskonalenia. Nauczyciel powinien być dla ucznia nie tyle autorytetem, ile przyjacielem, doradcą, empatycznym, otwartym, akceptującym, umiejącym słuchać i rozumieć, partnerem działającym wspólnie z uczniem w dążeniu do wspólnego celu ${ }^{24}$.

W literaturze poświęconej problematyce stylów nauczania, będących wyrazem indywidualnego podejścia do nauczania i uczącego się istnieje wiele klasyfikacji. Rozpatrując kompetencje terapeutyczne nauczyciela warto wyróżnić styl terapeutyczny ${ }^{25}$ opracowany przez Garyego Fenstermachera oraz Jonasa Soltisa ${ }^{26}$. Styl terapeutyczny ukształtował się na bazie orientacji terapeutycznej w psychologii humanistycznej. Nauczyciel uczący stylem terapeutycznym staje się klasowym psychologiem, osobą wspomagającą emocjonalny i duchowy stan ucznia, biorącą czynny udział w procesie kształtowania się osobowości i świadomości uczniów, ułatwiając im samorealizację, zrozumienie siebie oraz akceptację. Na pierwszym planie stawia się potrzeby i zainteresowania uczniów, ich motywacje i styl poznawania. Praca z uczniem ma

24 M. Feiner, Ku nowym sposobom myślenia i praktykowania pedagogicznego, „Edukacja. Studia-Badania-Innowacje" 1995, nr 3, s. 10-12.

25 Autorzy oprócz terapeutycznego stylu nauczania wyodrębnili także styl kierowniczy oraz wyzwalający.

26 G.D. Fenstermacher, J.F. Soltis, Style nauczania, WSiP, Warszawa 2000, s. 24-25. 
charakter swobodny, podporządkowany indywidualnemu rozwojowi każdego podopiecznego i skierowana jest na samodzielne wybory oraz relacje interpersonalne ${ }^{27}$. Dobry klimat emocjonalny jest istotnym elementem w procesie nauczania, gdyż odkrywanie budzi fascynację wśród uczniów, chęć i mobilizację do nauki, natomiast nagradzanie następuje po ocenie całokształtu pracy. Głównym zadaniem nauczyciela jest pomoc uczniowi w wyborze treści nauczania i sposobu wykorzystania jej, gdy skonfrontuje się z rzeczywistością, w której będzie musiał wybrać własną drogę. Styl ten skierowany jest nie tylko na uczniów ze specjalnymi potrzebami, ale na wszystkich uczniów pracujących w małych grupach ${ }^{28}$. W podejściu terapeutycznym nauczyciel charakteryzuje się empatią. Empatyczny nauczyciel potrafi widzieć świat w sposób postrzegany przez dziecko, prawidłowo odbiera jego uczucia i stojące za nimi przeżycia, co sprawia, że jest w stanie dać swoim uczniom poczucie bezpieczeństwa. Nauczyciel taki potrafi stanąć w obronie interesów dziecka, stara się zrozumieć jego zachowanie w różnych sytuacjach szkolnych, wczuć w jego psychikę i odpowiednio zdiagnozować przyczyny jego problemów, dzięki czemu skuteczniej może mu pomóc.

Korzystając z umiejętności terapeutycznych nauczyciel powinien pomóc uczniowi w zrozumieniu i wyjaśnieniu jego problemów i trudności. Trzeba zachować cierpliwość, kiedy uczeń zmaga się ze swoimi problemami. Czasem rozwiązania są dla nauczyciela oczywiste, ale warto czekać aż uczeń znajdzie je sam. Sztuka polega na tym, żeby stworzyć warunki ułatwiające ten proces $^{29}$. Zadaniem terapeuty jest zastosowanie „takich strategii interwencji, które sprawią, że terapia będzie prosta, interesująca i skuteczna"30.

Umiejętności terapeutyczne, które można zaliczyć do podstawowych elementów kompetencji nauczyciela to: ${ }^{31}$

- umiejętność dostrzegania i rozpoznawanie emocji ucznia,

- umiejętność empatycznego rozumienia i asertywności,

\footnotetext{
Ibidem, s. 32-42.

Ibidem, s. 25.

G. King, Umiejętności terapeutyczne nauczyciela, GWP, Gdańsk 2003, s. 71.

J.A. Heaton, Podstawy umiejętności terapeutycznych, GWP, Gdańsk 2003, s. 112.

Por. I. Rudek, Poznawanie ucznia i diagnozowanie wychowawcze jako konieczne umiejętności nauczyciela, [w:] K. Ferenz, E. Kozioł (red.) Kompetencje nauczyciela-wychowawcy, Wydawnictwo Uniwersytetu Zielonogórskiego, Zielona Góra 2002, s. 131.
} 
- umiejętność dostrzegania i spełniania potrzeb ucznia,

- umiejętność dostrzegania mocnych stron ucznia,

- umiejętność efektywnego komunikowania się, dialogu,

- umiejętność pełnej akceptacji ucznia,

- umiejętność wspierania, wzmacniania i pobudzania ucznia,

- umiejętność rozwiązywania konfliktów,

- umiejętność wywierania wpływu na innych,

- umiejętność pomagania,

- umiejętność współpracy i współdziałania.

Terapeutyczna wiedza pedagoga powinna być funkcjonalna, warunkująca skuteczną organizację pracy terapeutycznej oraz uwzględniająca potrzeby i możliwości dziecka. Powinna dotyczyć psychologicznych i pedagogicznych aspektów kształtowania osobowości dziecka, wyjaśniania mechanizmów powstawania i zaspokajania potrzeb, prawidłowości rozwoju intelektualnego, psychicznego i społecznego, wiedzy o zaburzeniach, które utrudniają lub wręcz uniemożliwiają realizację programu nauczania.

Bogusława D. Gołębniak za nadrzędne dla warsztatu nauczyciela profesjonalisty uznaje m.in. umiejętność diagnozowania i monitorowania rozwoju ucznia, mierzenia indywidualnego progresu; rozpoznawania szczególnych uzdolnień i potrzeb edukacyjnych, formułowania wobec uczniów oczekiwań odpowiednich do ich wieku, zdolności, poziomu rozwoju; stosowania różnorodnych strategii edukacyjnych; kreowania środowiska uczenia się ${ }^{32}$.

Osoby „profesjonalnie pomagające” muszą spełniać trzy kryteria, czyli posiadać umiejętności skutecznego komunikowania się, posiadać wiedzę o rozwoju człowieka oraz umiejętności diagnostyczne. Natomiast osoby „pomagające nieprofesjonalnie” nie muszą posiadać umiejętności diagnostycznych ${ }^{33}$.

Wobec dynamiki szeroko pojętych przemian nauczyciel musi przyjąć rolę pomocnika w procesie edukacji ustawicznej i obrać rolę nauczyciela budującego w procesie kształcenia „pomosty” pomiędzy

32 B.D. Gołębniak, Zmiany edukacji nauczycieli. Wiedza - biegłość - refleksyjność, Wydawnictwo Edytor, Toruń - Poznań 1998, s. 160-161.

33 R. Parol, Rozwijanie umiejętności terapeutycznych, [w:] E. Przygońska, I. Chmielewska (red.), Nauczyciele wobec wyzwań współczesności: doświadczenia - badania koncepcje, Wydawnictwo Wyższej Szkoły Humanistyczno-Ekonomicznej, Łódź 2009, s. 47-48. 
możliwościami i potrzebami uczniów a wymogami współczesności. Musi optymalnie zaktywizować uczniów, ukierunkować ich i wskazać sens budowania wiedzy i umiejętności - ukazać im znaczenie samokształcenia i edukacji ustawicznej. Konstruując relacje z uczniami oparte na szacunku dla indywidualności, akceptacji autorskich idei, $\mathrm{w}$ poczuciu bezpieczeństwa pomaga uczniom dostrzec tkwiący w nich potencjał, zauważyć własne możliwości oraz docenić własne sukcesy, jak i porażki - ponieważ niekiedy błędy uczą najwięcej, a wyprowadzone z nich wnioski są pamiętane najdłużej. Nauczyciel pomagający towarzyszy uczniowi, prowadzi go pozostając z tyłu, pomaga nie tylko w opanowaniu tematu, ale też w rozwijaniu umiejętności samodzielnego uczenia się ${ }^{34}$. Stojąc niejako „w cieniu” potencjału ucznia „czuwa” nad jego właściwym rozwojem, jedynie podpowiadając kierunek, w jakim powinien podążać. Pomaga swojemu uczniowi w drodze ku jego samodzielności intelektualnej, w procesie jego samorozwoju. „Nauczyciel powinien być gotowy pomóc uczniowi w dążeniu do samodzielności, ale powstrzymywać się od pomagania wtedy, gdy nie jest to potrzebne"35. Nauczyciel zachęca uczniów do samodzielności, oferując własną pomoc wówczas, kiedy jest to konieczne i niezbędne. Czuwa jednak nad tym, aby uczniowie pracowali z pełną świadomością własnej roli, odpowiedzialnie, z pełnym zaangażowaniem, pozwalając przy tym na popełnianie błędów - one również stają się doskonałą szansą nauki i zdobywania doświadczeń. Konstruując proces edukacyjny nauczyciel powinien dążyć do poznania potencjału swoich uczniów i kłaść szczególny nacisk na indywidualizację kształcenia, wykorzystywać optymalne metody i formy pracy oraz najefektywniejsze strategie dochodzenia do celu.

\section{Podsumowanie}

$\mathrm{Z}$ analizy obecnego systemu oświatowego wynika, że niezwykle znacząco uległa zmianie rola nauczyciela w tym procesie. Jest ona zdecydowanie trudniejsza niż wcześniej. Nauczyciel nie może wymuszać na uczniach realizowania zadań współczesnej edukacji. W zamian powinien ich motywować i inspirować, pomagać rozwijać ich poznawcze

34 G. Petty, Nowoczesne nauczanie, GWP, Sopot 2010, s. 340.
35 Ibidem. 
zainteresowania, zapewniać ku temu odpowiednie warunki, wspierać swoich wychowanków w realizacji ich celów. Nauczyciel nie powinien obecnie odgrywać pierwszoplanowej roli w procesie dydaktyczno-wychowawczym, lecz niejako z odpowiednim zdystansowaniem pozostawać w tle organizatorem, koordynatorem i kierownikiem tego procesu.

Kompetencje terapeutyczne nauczyciela to takie, o które warto zabiegać w procesie kształcenia pedagogicznego nauczycieli. Jednak należy też pamiętać, że te kompetencje powinny wynikać z głębokich cech wewnętrznych kandydatów na nauczycieli, ich immanentnych cech osobowości, wówczas bowiem edukacja i wychowanie stają się dobrowolną relacją interpersonalną, opartą na szacunku wobec wysoko cenionej osoby, współistnieniem wynikającym z fascynacji i chęci współdziałania z drugim człowiekiem. Dobrowolność interakcji połączona z szacunkiem i podziwem dla dokonań i osobowości nauczyciela mobilizuje wychowanka do aktywności poznawczej, intelektualnej, do działalności twórczej i inicjuje szeroko pojęte zmiany, stając się swoistym katalizatorem dla rozwoju osobistego ucznia i jego nauczyciela ich obustronnego i współzależnego wpływu edukacyjnego.

Dzięki kompetencjom terapeutycznym nauczyciel w codziennej pracy dydaktyczno-wychowawczej może w porę dostrzec trudności i zdolności dziecka, rozpoznać jego indywidualne możliwości psychofizyczne oraz potrzeby rozwojowe i edukacyjne. Umiejętności terapeutyczne pomagają nauczycielowi kształtować stosunek dziecka do stawianych mu wymagań poprzez odpowiednią reakcję na sukcesy i porażki szkolne. Nauczyciel może uczynić, że dziecko będzie umiało skorzystać z własnych możliwości i umiejętności oraz uwierzy w siebie i swój sukces. Powinien także nauczyć dziecko właściwego przeżywania sytuacji niepowodzenia oraz sposobów wychodzenia $\mathrm{z}$ opresji, radzenia sobie z porażką. Nauczyciel musi posiąść umiejętność odkrywania tego, co się dzieje z dzieckiem, na czym polega problem, co się na niego składa i co prawdopodobnie w największym stopniu pomoże w jego rozwiązaniu ${ }^{36}$. Można więc stwierdzić, iż edukacja potrzebuje nauczycieli refleksyjnych, którzy postawieni wobec sytuacji problemowej, umieją się z nią uporać przez uruchomienie swojej wiedzy i doświadczenia na rzecz rozwiązania problemu ${ }^{37}$.

36 Por. J.A. Kottler, Skuteczny terapeuta, GWP, Gdańsk 2003, s. 110.

37 R. Muszkieta, Nauczyciel w reformującej się szkole, Wydawnictwo Nowa Era, Poznań 2001, s. 11. 
Podejście wspomagające musi być refleksyjne, aby było skuteczne i podmiotowe, bo wtedy pozwala na lepsze zrozumienie indywidualnych problemów ucznia, zastanowienie się nad ich przyczyną, ale też daje przestrzeń dla osobistych przemyśleń i swobodnych działań kreatywnych. Rozumienie, otwartość, elastyczność i odpowiedzialność to kluczowe cechy refleksyjnego praktyka, które mają stanowić ważny element kompetencji doradczych, pomocowych, terapeutycznych nauczyciela, którego powinnością jest nie tylko podejmowanie dyrektywnych działań, ale rozumienie faktów pedagogicznych i przekształcanie bieżącej rzeczywistości ${ }^{38}$.

Koncepcja terapeutycznego podejścia w nauczaniu jest ideą wskazującą na możliwości i szanse mądrego (świadomego) wykorzystania przez nauczyciela jego własnego doświadczenia i wynikających z niego wniosków interpretacyjnych - refleksji nad własną praktyką, interpretacji własnych działań, osiągnięć - sukcesów i porażek zarówno swoich, jak i w odniesieniu do uczniów. Jest ideą roli opartej na aktywnym i ustawicznym budowaniu własnego mistrzostwa pedagogicznego, kiedy to głęboka analiza własnego doświadczenia, poparta wiedzą teoretyczną staje się źródłem twórczego działania nauczyciela i komponentem jego profesjonalizmu pedagogicznego. W związku z powyższym koncepcja ta jest ideą akcentującą indywidualność, zmienność i progresywność roli społeczno-zawodowej nauczyciela, szczególnie wartościową w obszarze pomocowym i wspomagającym rozwój uczniów.

\begin{abstract}
The subject of the article are the therapeutic competence of the teacher. The subject of the article is the therapeutic competence of the teacher. It is based on the therapeutic orientation in humanistic psychology. These competences allow the teacher to see in time the difficulties and abilities of a child, recognize their individual psychophysical possibilities as well as development and educational needs. The concept of therapeutic approach in teaching is aimed at taking actions favouring the development of students' potential in order to increase the effectiveness of learning and improve their functioning. The article emphasizes the teacher's skills particularly valuable in the area of assistance and support for student development.
\end{abstract}

38 B. Skałbania, T. Lewandowska-Kidoń, Pomoc psychologiczno-pedagogiczna w szkole - między rutyna a refleksyjna praktyka, „Lubelski Rocznik Pedagogiczny” 2016, t. 35 , z. 1 , s. 162 . 


\section{Bibliografia}

Czerepaniak-Walczak M., Aspekty i źródła profesjonalnych refleksji nauczyciela, Wydawnictwo Edytor, Torun 1997.

Czerepaniak-Walczak M., Refleksja krytyczna i jej miejsce w dyskusji nad reformowaniem oświaty, „Rocznik Pedagogiczny”, t. 20.

Denek K., Podmiotowość w procesie kształcenia, „Wychowanie na co Dzień" 2003.

Dunaj B. (red.), Słownik współczesnego języka polskiego, PWN, Warszawa 1996.

Feiner M., Ku nowym sposobom myślenia i praktykowania pedagogicznego, „Edukacja. Studia-Badania-Innowacje” 1995, nr 3.

Fenstermacher G.D., Soltis J.F., Style nauczania, WSiP, Warszawa 2000.

Gołębniak B.D., Zmiany edukacji nauczycieli. Wiedza - biegłość - refleksyjność, Wydawnictwo Edytor, Toruń - Poznań 1998.

Goźlińska E., Szlosek F., Podręczny słownik nauczyciela kształcenia zawodowego, Wydawnictwo Instytut Technologii Eksploatacji, Radom 1997.

Heaton J.A., Podstawy umiejętności terapeutycznych, GWP, Gdańsk 2003.

King G., Umiejętności terapeutyczne nauczyciela, GWP, Gdańsk 2003.

Kottler J.A., Skuteczny terapeuta, GWP, Gdańsk 2003.

Łobocki M., Czynniki warunkujące skuteczność pracy wychowawczej, [w:] M. Łobocki (red.), Praca wychowawcza z dziećmi i młodzieża, Wydawnictwo Uniwersytetu Marii Curie-Skłodowskiej, Lublin 2001.

Muchacka B., Szymański M., Kompetencje jako transgresyjny potencjał nauczycieli, [w:] B. Muchacka, M. Szymański (red.), Nauczyciel w świecie współczesnym, Oficyna Wydawnicza „Impuls”, Kraków 2008.

Muszkieta R., Nauczyciel w reformującej się szkole, Wydawnictwo Nowa Era, Poznań 2001.

Okoń W., Nowy słownik pedagogiczny, Wydawnictwo Akademickie Żak, Warszawa 2004.

Parol R., Rozwijanie umiejętności terapeutycznych, [w:] E. Przygońska, I. Chmielewska (red.), Nauczyciele wobec wyzwań współczesności: doświadczenia - badania-koncepcje, Wydawnictwo Wyższej Szkoły Humanistyczno-Ekonomicznej, Łódź 2009.

Petlak E., Klimat szkoły. Klimat klasy, Wydawnictwo Akademickie Żak, Warszawa 2007.

Petty G., Nowoczesne nauczanie, GWP, Sopot 2010.

Průcha J., Pedeutologia, [w:] B. Śliwerski (red.), Pedagogika, t. 2: Pedagogika wobec edukacji, polityki oświatowej i badań naukowych, przekł. B. Śliwerski, GWP, Gdańsk 2006. 
Rogers C., O stawaniu się sobą, Dom Wydawniczy REBIS, Poznań 2002. Rogers C., Sposób bycia, Dom Wydawniczy REBIS, Poznań 2002.

Rozporządzenie Ministra Edukacji Narodowej z dnia 9 sierpnia 2017 r. w sprawie organizacji i udzielania pomocy psychologiczno-pedagogicznej w przedszkolach, szkołach i placówkach, Dz.U. 2017, poz. 1591 z poźn. zm.

Rudek I., Poznawanie ucznia i diagnozowanie wychowawcze jako konieczne umiejętności nauczyciela, [w:] K. Ferenz, E. Kozioł (red.) Kompetencje nauczyciela-wychowawcy, Wydawnictwo Uniwersytetu Zielonogórskiego, Zielona Góra 2002.

Skałbania B., Lewandowska-Kidoń T., Pomoc psychologiczno-pedagogiczna w szkole - między rutyną a refleksyjna praktyką, „Lubelski Rocznik Pedagogiczny" 2016, t. 35, z. 1.

Strykowski W., Szkoła współczesna $i$ zachodzace w niej procesy, [w:] W. Strykowski, J. Strykowska, J. Pielachowski (red.), Kompetencje nauczyciela szkoły współczesnej, Wydawnictwo eMPi², Poznań 2003.

Szempruch J., Nauczyciel w zmieniającej się szkole - funkcjonowanie i rozwój zawodowy, Wydawnictwo Oświatowe FOSZE, Rzeszów 2001.

Tokarski J. (red.), Słownik wyrazów obcych, PWN, Warszawa 1980.

Wosik-Kawala D., Zubrzycka-Maciąg T. (red.), Kompetencje diagnostyczne i terapeutyczne nauczyciela, Oficyna Wydawnicza „Impuls”, Kraków 2011.

Woźniak I., Standard kwalifikacji zawodowych jako łącznik między wymaganiami rynku pracy a edukacja zawodowa, [w:] S.M. Kwiatkowski, I. Woźniak (red.), Standardy kwalifikacji zawodowych $i$ standardy edukacyjne. Relacje-modele - aplikacje, IBN, Warszawa 2002.

\section{Netografia}

Brasławska-Haque M., Kompetencje terapeutyczne współczesnego nauczyciela, http://rep.up.krakow.pl/xmlui/bitstream/handle/11716/ 169/0051_20150303_mg_ra_kompetencje_terapeutyczne_wspolczesnego_m_braslawska.pdf?sequence=1\&isAllowed=y (dostęp: 10.09.2019). 